\title{
CONTACT BETWEEN NON-RESIDENT PARENTS AND THEIR CHILDREN DURING THE COVID-19 PANDEMIC IN HUNGARY
}

\author{
IVETT SZALMA
}

Several studies have examined the factors that can influence contact between non-resident parents and their children (Goldberg \& Carlson 2015, Skevik 2006). The distance between the place of residence of the non-resident parent and their child(ren) has been found to be important in terms of the frequency of in-person contact (Manning et al. 2003; Cheadle et al. 2010). The majority of research on this topic focuses on the frequency and quality of face-to-face visitation between non-resident parents and their children (Kalmijn, 2015, Köppen et al., Szalma \& Rékai 2019). Although some studies have explored other types of contact such as overnight stays (Haux \& Platt, 2020; King et al. 2004) and phone contact (Leite \& McKenry, 2002; Meggiolaro \& Ongaro, 2014), these remain marginal. Other types of communications between non-resident parents and their children might be under-researched because face-to-face contact is a condition for other types of contact (Schier 2016).

Based on earlier research findings, we addressed how forms of contact were influenced during the first wave of the COVID-19 pandemic (which can be dated to the spring of 2020) in Hungary. One of our research questions was whether face-to face contact patterns were still dominant, or whether the role of ICT had changed contact between non-resident parents and their children in Hungary due to COVID-19. Furthermore, we also examined the changes in the frequency of face-to face contact and the source of these kinds of changes.

In order to answer these questions, I and my colleague, Krisztina Rékai (a BA student at the University of Warwick), conducted 22 semi-structured telephone interviews between 24 March and 5 April with individuals from different

\footnotetext{
1 Ivett Szalma is a research fellow at the Center for Social Sciences, Hungarian Academy of Sciences Centre of Excellence, and associate professor at the Corvinus University of Budapest, e-mail: szalma.ivett@tk.hu. She was supported by the János Bolyai Research Scholarship of the Hungarian Academy of Sciences and the New National Excellence Programme (ÚNKP-19- 4-BCE-11) of the Ministry for Innovation and Technology.
} 
geographical areas within Hungary. This period was a rather unique time, due to the partial curfew that lasted from 28 March to 11 April. Our selection criteria were parents who had at least one child under the age of 18 but did not live in the same household as the other parent. We managed to conduct 22 interviews. Our sample included 12 non-resident fathers and six parents who had shared custody arrangements, as well as fourresident mothers. This allowed us to obtain a fuller picture of the changes in contact between non-resident parents and their children during the pandemic.

Individual interviewees were easily recruited because most of them had participated in a previous piece of research by the authors that focused on how non-resident parents are involved in the lives of their children in different dimensions (Szalma - Rékai 2019). All the interviewees (i.e. those who had participated in the previous research and the new ones) were recruited through the snowball method. Thus, we already had lots of background information about the interviewees who had participated in our earlier research, so we could just focus on the changes due to the special circumstances. For this reason, most of our interviews with the latter lasted about 20 minutes, and interviews with newly involved interviewees lasted around 40 minutes. Before starting the interview process, we asked for interviewees' informed consent and explained that the data collection procedures were confidential and based on their voluntary participation. It was interesting that no one refused to participate. Indeed, respondents were eager to share their concerns about the pandemic situation. The interviews were tape-recorded, and the recorded interview material was first transcribed verbatim. Transcripts were then transformed into a code book by applying structural coding in an excel file.

Our results show that under special circumstances parental visitations were affected. Nine interviewees reported the complete suspension of visits during the pandemic. Six participants among the latter said that they had terminated personal meetings with their children because at least one or the other parents had evaluated the pandemic-related risk as too high for face-to-face visitation. This was surprising, because the partial curfew announced by the Hungarian government on 28 March stated that parental- and visitation rights should not be affected by the restriction-of-movement policy. In the other three cases, the cessation of encounters occurred due to the indirect effects of the virus, such as borders being closed and individuals being forced to stay in quarantine. Furthermore, six out of the twenty-two participants had significantly changed their meeting habits in some way, and only in seven cases were no kinds of change detected at the time of the interviews (Szalma - Rékai 2020).

As for the role of ICT, we found that it had increased because, when personal visitation did not take place, resident parents in all cases helped non-resident 
parents to keep contact with their children via ICT. Julia, for example, did not support the use of a mobile phone between her eight-year-old son and his father, but she explained that at the time she had allowed it because it could help the latter remain in contact in the absence of in-person meetings. An earlier study (Rudi et al. 2015) found that those non-resident fathers who lived far away from their children highlighted the importance of online connections. We also noticed that social distancing could cause similar effects with regard to contact between non-resident parents and their children as the effects caused by significant (geographical) physical distance (Szalma - Rékai 2020).

While this research allowed us to obtain some insight into contact between non-resident parents and their children during the pandemic, it also revealed that most of the non-resident parents reported only temporary changes related to developments in the pandemic situation (Szalma - Rékai 2020). For example, Steven described the frequency of personal meetings with his daughter in the following way: "It is hectic, because it depends on the mothers' feelings towards the virus at the time. Last week, for example, she decided that for some reason the child couldn't come to visit all week. Today she told me to come for the little girl right now." Since we were only able to take a snapshot of the situation, I decided to continue the research. During the summer of 2020 (between 1 July and 30 August) I conducted follow-up research. Thus, I re-contacted all the interviewees and asked them to report whether they had maintained their original strategy during the whole period of the first wave of the COVID-19, or if any changes had occurred by the end of the first wave. My preliminary results show that were significant changes compared to the earlier snapshot.

The most notable changes in relation to visitation occurred with those parents who had earlier chosen not to permit any personal contact between their expartners and their children. For example, Julia reported that "it was not feasible [to stop them seeing each other], because when I made the decision not to meet, I thought that they would be separated for a maximum of one-and-a-half months, and then it would be over. It is not normal that my son does not meet his father for months. I told him to follow the safety guidelines, apply strict hygiene - everything that was officially requested - and I allowed him to go back." It seems that total isolation was not a feasible strategy, because all of the nine interviewees had changed their original strategy by the end of the first wave of COVID-19.

Additionally, some indirect effect of the pandemic - such as the introduction of home office work and online education - also required some rethinking of earlier plans. For example, John reported that he and his wife were not able to continue the physically joint custody because of the burden of online education, and that his child's grandmother had carried all the weight, and that both he 
and his ex-wife had become "weekend parents" - and then only every two weeks. Furthermore, our follow-up revealed that, in addition to the pandemic's direct and indirect effects, other life events such as having new partnerships or moving to a new residence influenced the patterns of contact between nonresident parents and their children. Moreover, most of the interviewees reported that during the summer period they typically adopted a different schedule than during the school year. For example, Thomas said the following "Of course, just like before the virus... We went back to face-to-face meetings, with no change." Most of the interviewees also considered the summer period to be a "COVID-19 free" period.

I would like to continue this research, because the second wave of COVID-19 is probably having different effects on people's lives. Kindergartens and primary schools are still open, and there is no strict partial curfew, unlike during the first wave of COVID-19, although the number of deaths and infected persons is much higher in the second wave than it was in the first in Hungary. These facts may have a different effect on people's behaviors than we experienced during the first wave. However, as we learned from the previous research that parents' strategies were quite fluid during the first wave of COVID-19, I would like to wait with the second follow up until the end of the second (third) wave, then re(re)contact panel participants.

\section{REFERENCES}

Cheadle, J. E., P. R. Amato, and V. King (2010) Patterns of Nonresident Father Contact. Demography, Vol. 47, No. 1. Pp. 205-225, DOI: 10.1353/dem.0.0084. Goldberg, J. S., and Carlson, M. J. (2015) Patterns and Predictors of Coparenting after Unmarried Parents Part. Journal of Family Psychology: JFP: Journal of the Division of Family Psychology of the American Psychological Association (Division 43), Vol. 29, No.3., pp.416-426, DOI: 10.1037/ fam0000078.

Haux, T., \& Platt, L. (2020) Fathers' Involvement with Their Children Before and After Separation. European Journal of Population. DOI:10.1007/s10680020-09563-z

Kalmijn, M. (2015) Father-child relations after divorce in four European countries: Patterns and determinants. Comparative Population Studies, Vol. 40, No. 3., 251-276. DOI:10.12765/CPoS-2015-10en

King, V., Harris, K. M., \& Heard, H. E. (2004) Racial and ethnic diversity in nonresident father involvement. Journal of Marriage and Family, Vol. 66, No. 1., pp. 1-21. DOI:10.1111/j.1741-3737.2004.00001.x 
Köppen, K., M. Kreyenfeld, and H. Trappe (2018) Loose Ties? Determinants of Father-Child Contact after Separation in Germany. Journal of Marriage and Family, Vol. 80, No. 5., pp. 1163-1175. DOI: 10. 1111/jomf.12504.

Leite, R. W., and McKenry. P. C. (2002) Aspects of Father Status and Postdivorce Father Involvement with Children. Journal of Family Issues, Vol. 23, No. 5., pp.601-623. DOI: 10.1177/ 0192513X02023005002.

Manning, W. D., S. D. Stewart, and P. J. Smock (2003) The Complexity of Fathers' Parenting Responsibilities and Involvement with Nonresident Children.Journal of Family Issues, Vol. 24, No5., pp. 645-667. DOI: 10.1177/0192513X03024005004

Meggiolaro, S., and F. Ongaro (2015) Non-Resident Parent-Child Contact after Marital Dissolution and Parental Repartnering: Evidence from Italy. Demographic Research, Vol.33, No. 40., pp.1137-1148. DOI

Rudi, J., J. Dworkin, S. Walker, and J. Doty (2015) Parents' Use of Information and Communications Technologies for Family Communication: differences by Age of Children. Information, Communication \& Society, Vol. 18, No. 1., pp.78-93. DOI: 10.1080/1369118X.2014.934390.

Schier, M. (2016) Everyday Practices of Living in Multiple Places and Mobilities: Transnational, Transregional, and Intra-Communal Multi-Local Families. In M. Kilkey \& E. Palenga-Möllenbeck (Eds.), Family Life in an Age of Migration and Mobility: Global Perspectives through the Life Course (pp. 43-69). London: Palgrave Macmillan UK.

Skevik, A. (2006) Absent fathers' or 'reorganized families'? Variations in father-child contact after parental break-up in Norway. The Sociological Review, Vol. 54, No. 1., pp., 114-132. DOI:10.1111/j.1467-954X.2006.00604.x Szalma, I., and Rékai, K. (2019) Szülői felügyeleti jog, kapcsolattartás és tartásdijfizetés a különélő magyar szülők gyakorlatában [Parental Custody, Visitation and Child Support among Non-Resident Parents in Hungary]. Szociológiai Szemle, Vol. 29, No.4., pp. 83-114.

Szalma, I., and Rékai, K. (2020) Personal and Online Contact during the COVID-19 Pandemic among Nonresident Parents and their Children in Hungary. International Journal of Sociology, DOI: 10.1080/00207659.2020.1786635 
